\title{
GaMelLED: Kaedah Pensampelan Audio Keromong Dalam Pembangunan Keromong Elektronik
}

\author{
Nazimin Bin Nazeri ${ }^{1}$, Zaharul Lailiddin Bin Saidon, Affendi Bin Ramli \\ Universiti Pendidikan Sultan Idris, Malaysia \\ 1emel: naziminnazeri@yahoo.com
}

Diterbitkan dalam talian: 26 December 2020

Cite this article (APA): Nazeri, N., Saidon, Z. L., \& Ramli, A. (2021). GaMelLED: Kaedah pensampelan audio keromong dalam pembangunan keromong elektronik. Jurai Sembah, 2(1), 1-11. https://doi.org/10.37134/juraisembah.vol1.2.4.2020

\begin{abstract}
Abstrak
Artikel ini adalah berdasarkan kepada satu kajian yang dijalankan dengan tujuan untuk membangunkan dan mengaplikasi keromong elektronik yang dinamakan GaMelLED Keromong. Fokus artikel ini adalah untuk membincangkan kaedah pensampelan audio keromong yang merupakan salah satu fasa yang digunakan dalam kajian. Sampel audio memainkan peranan penting bagi GaMelLED Keromong kerana dapat memberi impak dalam pengaplikasian alat bersama karya kreatif yang dipersembahkan. Kajian ini dilaksana melalui pendekatan practice-led research yang mana proses kreatifnya meliputi kaedah-kaedah yang merangkumi seperti (a) analisis media; (b) cuba jaya; (c) rakan kritikal; dan (d) jurnal refleksi. Dapatan kajian ini mendapati bahawa pensampelan audio yang dinamakan Kaedah Pantul dapat meningkatkan kualiti sampel audio keromong dari aspek pengurangan frekuensi bising di sekitar $125 \mathrm{~Hz}-8 \mathrm{kHz}$, kualiti pelarasan yang lebih tepat tanpa suntingan digital dan nada yang lebih jelas. Hasil kajian dapat menyumbang kepada kaedah baharu bagi pensampelan audio keromong terhadap elemen teknikal rakaman menggunakan peralatan yang minima dengan hanya memanipulasikan posisi keromong yang dirakamkan.
\end{abstract}

Kata Kunci: Gamelan Melayu, keromong, practice-led research, recording techniques, sampling audio

\begin{abstract}
This article is based on a study conducted with the aim of developing and applying an electronic keromong knowned as GaMelLED Keromong. The focus of this article is to discuss keromong's audio sampling method which is one of the phases used in the study. Audio samples play an important role in GaMelLED Keromong because it has the impact in the application of GaMelLED Keromong along with the creative work presented. This study uses practice-led research approach where the creative process includes methods such as (a) media analysis; (b) trial and error; (c) critical friend; and (d) reflective journal. The outcome of the study disclosed that audio sampling known as Reflective Method can improve the quality of keromong audio samples from the aspect of noise frequency reduction around 125 $\mathrm{Hz}-8 \mathrm{kHz}$, more accurate pitch without digital editing and clearer tone. The research can also contribute to a new method for keromong audio sampling in the technical elements of recording using minimal equipment by simply manipulating the position of keromong.
\end{abstract}

Keywords: Gamelan Melayu, keromong, practice-led research, recording techniques, sampling audio

\section{Pengenalan}

Teknologi muzik kian maju lantas menyumbang kepada pelbagai aspek di antaranya adalah inovasi dalam pembangunan alat muzik akustik mahupun elektronik. Inovasi yang telah dibangunkan dapat digunakan dalam pembangunan pelbagai perisian mahupun alat komunikasi termasuk telefon pintar. Bagi kemajuan dalam aspek aplikasi gamelan digital dalam telefon pintar, ianya sangat membantu dan mudah untuk diakses oleh pengguna khususnya pelajar. Teknologi ini telah dibangunkan disebabkan faktor harga gamelan yang mahal, saiz yang besar (Engkur et al., 2019) serta tidak mempunyai kemudahalihan (Shafik et al., 2014). 
Namun begitu, terdapat kesukaran untuk memainkan alat muzik yang telah dibangunkan menggunakan aplikasi telefon pintar atau pada Musical Instrument Digital Interface (MIDI) kibod. Kesukaran yang dihadapi berkaitan permainan alat muzik gamelan dalam aplikasi telefon pintar atau MIDI kibod adalah pemuzik tidak dapat menggunakan teknik pukulan sepertimana alat muzik gamelan dimainkan secara tradisional.

Oleh itu, satu kajian dalam membangunkan alat muzik elektronik berasaskan alat muzik gamelan iaitu keromong telah dijalankan dengan fokus alat muzik keromong elektronik dimainkan secara ketukan. Mekanisma ketukan diperlukan bagi alat muzik keromong elektronik berdasarkan dari ciri utama memainkan gamelan iaitu melalui pukulan. Seperti yang dinyatakan oleh Tjahyanto et al. (2011), alat muzik gamelan merupakan alat muzik tradisional yang dimainkan dengan cara ketukan atau pukulan yang di mana keromong turut tergolong dalam alat muzik gamelan dan dimainkan dengan cara ketukan. Serasi dengan perkataan 'gamel' yang membawa maksud ditabuh atau dipukul (Jaafar, 2017). Berdasarkan kepada permasalahan yang dihadapi, satu kajian dilaksanakan bagi bertujuan untuk membangunkan keromong elektronik yang dinamakan GaMelLED Keromong iaitu salah satu alat muzik Gamelan Melayu yang dikenali sebagai keromong atau bonang (Sheppard, 1967). Terdapat beberapa fasa yang diperlukan dalam membangunkan GaMelLED Keromong dan di antaranya adalah fasa pensampelan audio. Artikel ini akan menfokuskan perbincangan mengenai analisis dan kaedah pensampelan audio keromong yang telah dihasilkan bagi digunakan dalam pembangunan dan pengaplikasian keromong elektronik.

Dalam konteks ini persoalan kajian yang memacu projek pembangunan ini adalah 'bagaimanakah pensampelan audio keromong dijalankan dalam pembangunan keromong elektronik?' Manakala objektif kajian ialah untuk menerangkan kaedah pensampelan audio dalam pembangunan keromong elektronik.

\section{Motivasi dan Inspirasi}

Pelbagai kajian berkaitan gamelan dan audio digital telah dijalankan (Craig \& Parry, 2019). Terdapat kajian yang berfokus kepada struktur sintesis harmonik yang unik bagi gamelan ensembel (Lydia, 1996), serta terdapat juga kajian yang fokus pada menotasikan algoritma semula jadi bagi jenis-jenis muzik gamelan seperti yang dilakukan oleh Matthews (2018). Terdapat juga kajian perisian komputer bagi penggunaan komposisi dalam mengaplikasikan proses teori muzik gamelan kepada notasi muzikal (Matthews, 2014; Hastuti \& Khabib, 2016; Gerd, 2008). Menurut Craig dan Parry (2019), terdapat pelbagai potensi memperkembangkan konsep bagi teori muzik gamelan sehingga kepada isyarat audio, lebih dari sekadar notasi nombor yang dapat digunakan dalam produksi audio dan reka bentuk audio. Selain itu, rakaman audio keromong turut menjadi kajian dalam mempelajari ilmu fizik bunyi (Anggraeni et al., 2019) serta dijalankan bagi menganalisis spektrum keromong yang mempunyai frekuensi overtone (Hamdan et al., 2019, 2020).

Motivasi dan inspirasi pengkaji bermula dari sifat ingin tahu amalan dalam kaedah pensampelan audio atau teknik rakaman keromong. Fokus artikel ini bermula apabila pengkaji membangunkan alat muzik elektronik atau pengawal MIDI yang dinamakan GaMelLED Keromong. Pengkaji mendapati bahawa keperluan untuk merakamkan audio keromong yang dapat digunakan bagi pengaplikasian GaMelLED Keromong dalam persembahan. Biarpun terdapat pelbagai sampel audio keromong dalam sintaksis seperti kibod, namun keunikan sampel audio keromong dilihat sebagai satu proses dalam memahami frekuensi overtone (Hamdan et al., 2019) yang unik serta mempunyai kaedah rakaman yang masih dapat diekplorasi. Oleh itu, satu proses rakaman audio yang dilimitasi hanya menggunakan alat muzik keromong dari institusi Universiti Pendidikan Sultan Idris dijalankan bagi mendapatkan sampel audio yang dapat digunakan bersama GaMelLED Keromong yang dibangunkan.

\section{Proses Kreatif}

Kajian ini dilaksana melalui pendekatan practice-led research (PLR) yang mana proses kreatifnya meliputi kaedah-kaedah yang merangkumi seperti (a) analisis media; (b) cuba jaya; (c) rakan kritikal; dan (d) jurnal refleksi. Dari aspek pensampelan audio, terdapat dua kaedah rakaman yang digunakan dalam kajian ini iaitu kaedah pertama yang digunakan dalam rakaman audio keromong (Hamdan et al., 2019, 2020) dan kaedah kedua merupakan kaedah baharu hasil dari cuba jaya oleh pengkaji yang dinamakan Kaedah Pantul. Rakaman dijalankan menggunakan keromong institusi Universiti Pendidikan Sultan Idris dan dirakam dalam studio gamelan yang mempunyai daya serapan bunyi atau bilik kedap bagi mengurangkan bunyi bising yang tidak diingini sepanjang proses rakaman berlangsung (Widayanti \& Pramudya, 2017). 
Penggunaan alat standard rakaman seperti wayar XLR seimbang, mikrofon, audio interface dan komputer digunakan dalam kedua-dua kaedah rakaman tanpa menukar sebarang alatan bagi memfokuskan dapatan kepada perbezaan kaedah rakaman dan bukannya dari aspek peralatan (Hamdan et al., 2019). Peranti interface ESI QuataFire 610, mikrofon jenis dinamik Shure SM57 dan juga mikrofon kondenser Samson Overhead digunakan sebagai alatan dalam menjalankan proses pensampelan.

Hasil daripada pensampelan audio menggunakan kedua-dua kaedah tersebut, audio dianalisis dan dicatatkan dalam jurnal refleksi bagi tujuan untuk mengemukakan pandangan, pemikiran dan pengarahan yang boleh berlaku apabila pengkaji melakukan refleksi dan mendokumentasikan amalan kreatif mereka sendiri (Smith \& Dean, 2009). Sampel audio yang telah dirakam diperdengarkan semula menggunakan pembesar suara kepada rakan kritikal bagi mendapatkan pandangan yang berbeza selain dari pengkaji (Stenhouse, 1975).

Menggunakan pendekatan PLR, artikel ini turut menyumbang kepada amalan proses pensampelan audio keromong dari aspek teoritikal berdasarkan kerangka amalan yang diadaptasi dari Smith dan Dean (2009). Bermula daripada perasaan ingin tahu tentang sesuatu amalan (Hill \& Lyold, 2015), pengkaji menggunakan inspirasi dan motivasi sebagai tunjang dalam mendalami amalan kaedah pensampelan audio yang dapat digunakan bersama keromong elektronik yang dibangunkan. Selain itu, pendekatan PLR ini memberi ruang dan peluang bagi pengkaji untuk lebih terbuka terhadap aspek kreativiti dan teori serta amalan dalam membangunkan proses yang unik untuk karya kreatif dan penyelidikan (Gray, 1996; Smith \& Dean, 2009).

\section{Analisis Media}

Penelitian awal bagi proses kreatif dimulakan dengan kaedah analisis media. Seiring dengan teknologi yang membangun, penggunaan media dilihat sebagai satu alternatif kajian atau penelitian yang memberi maklumat bagi membantu pengguna secara maya mendapatkan sebarang pengetahuan. Sebagai contoh media laman sesawang bagi bidang perubatan menyampaikan maklumat kepada pengguna, media video dalam bidang visual sosiologi atau antropologi digunakan oleh penggiat seni, dan penelitian bagi media seperti video dalam menganalisis amalan pengajaran digunakan sebagai rujukan kaedah pengajaran (Denecke, 2009; Knoblauch et al., 2006; Leblanc, 2018). Bagi kajian yang telah dijalankan, penelitian berkaitan rakaman audio gamelan khususnya terhadap bonang atau keromong dilakukan (Hamdan et al., 2019, 2020). Selain itu, pemerhatian media video di laman YouTube dijalankan bagi meneliti teknik rakaman yang digunakan dalam proses pensampelan audio keromong (Meizan, 2018; Chon, 2018). Fokus dalam kaedah analisis media adalah bagi mengenal pasti tetapan dan peralatan yang digunakan untuk tujuan rakaman dan analisis. Antara perkara yang dicatatkan adalah jenis peranti interface, jenis mikrofon dan jarak mikrofon (Hamdan et al., 2019, 2020; Meizan, 2018; Chon, 2018). Analisis media menggunakan perisian muzik atau Digital Audio Workstation (DAW) dijalankan setelah keromong dirakamkan. Analisis dilakukan menggunakan spektogram, multimeter dan juga audio analyzer.

\section{Cuba jaya}

Proses ini bertujuan untuk mencuba dan mendalami pelbagai pendekatan yang berkemungkinan menyumbang kepada kajian. Kunci kepada proses ini adalah perasaan ingin tahu yang merupakan sifat bagi practice-led research (Hill \& Lyold, 2015) yang mempunyai kepentingan operasional untuk sesuatu amalan (Candy, 2006). Kaedah cuba jaya digunakan dalam kajian disebabkan faktor pengetahuan yang tidak menyeluruh bagi pengkaji (Callander, 2011). Menurut Callander (2011), pengkaji akan belajar dengan memerhatikan pilihan terdahulu dan hasil yang telah disedari. Kaedah cuba jaya digunakan dalam kajian bagi menilai aspek pengetahuan yang telah melalui proses pengulangan (Miklaszewski, 1989; Young, 2009). Berdasarkan kajian yang telah dilakukan oleh Burkner (2017), kaedah atau amalan cuba jaya digunakan oleh penggiat muzik tempatan serta industri muzik khususnya dalam melakukan perubahan pengeluaran muzik mengikut peredaran zaman yang mana ianya adalah hasil cuba jaya oleh semua individu dalam industri muzik tempatan. Menurut Edwards (2004), kaedah cuba jaya merupakan antara teknik yang telah mapan untuk digunakan oleh pemula. Antara contoh penggunaan kaedah cuba jaya dalam kajian pensampelan audio ini adalah dalam menentukan jarak mikrofon dan keromong. Seterusnya kedudukan keromong diubah beberapa posisi bagi mendapatkan beberapa sampel audio yang berbeza. Cuba jaya turut 
digunakan bagi penerokaan kaedah baharu yang kemudiannya di analisis bagi melihat perbandingan yang terhasil dari dua kaedah rakaman yang digunakan.

\section{Rakan Kritikal}

Penglibatan rakan kritikal dalam proses pembangunan keromong elektronik adalah untuk mendapatkan pandangan atau kritikan dari kanta yang berbeza. Menurut Stenhouse (1975), rakan kritikal dilihat sebagai pasangan yang mampu memberi nasihat dan bekerjasama dalam kajian berdasarkan tindakan. Penglibatan rakan kritikal dilihat sebagai agen yang dapat menyumbang dalam kajian berbentuk 'self-study' (Garbett \& Ovens, 2018). Kaedah rakan kritikal digunakan bagi mendapatkan pandangan dari kanta berbeza serta untuk memeriksa amalan setiap pengkaji dan memberikan maklum balas bagi meningkatkan hasil kajian (Andreu et al., 2003). Bagi fasa pensampelan audio, rakan kritikal diperdengarkan beberapa sampel audio bagi mendapatkan pandangan dengan tujuan penambahbaikan dan catatan jurnal refleksi.

\section{Jurnal Refleksi}

Teknik merekod dan mencatat merupakan salah satu teknik yang telah digunakan di dalam kajian sebagai matlamat untuk pengkaji menilai perbuatan dan pengetahuan yang telah dilakukan (Schon, 1987). Kajian artikel ini juga turut menggunakan jurnal refleksi dalam proses kreatif bagi mendapatkan data yang holistik menggunakan pengalaman pengkaji sendiri (Dewey, 1933). Menurut Boud et al. (2001), penulisan jurnal boleh dilihat melalui kanta yang berlainan dan sebagai bentuk ungkapan diri serta sebagai rekod peristiwa atau sebagai bentuk terapi. Biarpun pengkaji akan mengalami sendiri pengalaman menjalankan kajian, namun begitu ianya tidak lengkap tanpa sebarang refleksi. Seperti yang dinyatakan oleh Boud et al. (1985), pengkaji tidak belajar dari pengalaman sebaliknya pengkaji belajar dari refleksi pengalaman dan menghubungkan refleksi tersebut sebaiknya.

Jurnal refleksi dijadikan sebagai satu dapatan yang dinamik sekiranya pengkaji dapat melihat secara menyeluruh dari setiap aspek (Schon, 1987). Terdapat pelbagai definisi bagi refleksi yang terdiri dari pelbagai jenis dan konseptual salah satunya menurut Korthagen (2011), refleksi adalah proses mental mencuba untuk menyusun atau menyusun semula pengalaman, masalah, pengetahuan atau pengetahuan yang sedia ada. Bagi kajian pensampelan audio keromong ini, jurnal refleksi dilihat sebagai satu kitaran proses kreatif yang sentiasa diperlukan oleh pengkaji bagi mendapatkan sampel audio yang mempunyai timbre serta frekuensi harmonik (Lydia, 1996; Hamdan et al., 2019) tanpa sebarang pelarasan digital.

\section{Pensampelan Audio}

Pensampelan audio adalah satu proses bagi menukar isyarat analog yang berterusan kepada urutan nombor digital (Mutagi, 2004). Pensampelan audio juga merupakan proses bagi merakam sumber bunyi satu bahagian pada satu masa, setiap bahagian yang dirakam kemudiannya dimasukkan ke dalam pensampel di dalam perisian muzik atau DAW. Kelebihan menjalankan proses pensampelan adalah bagi menjimatkan masa memainkan semula audio yang telah disampel serta mudah disimpan dan format yang boleh dibaca oleh komputer (McGuire \& Pritts, 2007). Kebiasaannya frekuensi audio bagi pensampelan adalah di dalam gandaan $44.1 \mathrm{kHz}$ atau $48 \mathrm{kHz}$ (Hummel, 2016). Nilai yang sepadan dengan amplitud diwakili oleh sistem digital dan ditunjukkan sebagai nilai digital 16 bit atau 24 bit.

Dalam kajian yang telah dijalankan, pengkaji menggunakan metod rakaman standard iaitu kadar 16 bit dan frekuensi $44100 \mathrm{~Hz}$ per sampel. Saiz penampan pula ditetapkan pada kadar 512 sampel bagi mengurangkan unsur lengah semasa rakaman dijalankan. Setelah tetapan bagi perisian dijalankan, mikrofon diletakkan dalam posisi pertama menghala ke arah keromong. Setiap buah keromong diketuk satu persatu dengan jarak $10 \mathrm{~ms}$ di antara setiap nada bagi mendapatkan jarak gelombang dan memudahkan suntingan dijalankan. Setiap buah keromong diketuk menggunakan aras kekuatan yang sama bagi mendapatkan halaju yang seimbang.

Posisi mikrofon diubah apabila sampel audio yang dirakam tidak menepati kehendak pengkaji. Biarpun bunyi itu dinilai secara subjektif (Fastl, 2013), namun terdapat keperluan bagi sampel audio yang dirakamkan mempunyai resonans yang panjang bagi mendapatkan estetika bunyi yang hampir sama seperti keromong dari aspek akustik. Konsep psikoakustik adalah seperti jambatan di antara dunia bagi pengukuran fizikal dan dunia penilaian subjektif (Fastl, 2013). Menurut Fastl (2013), antara contoh bagi menjelaskan 
konsep psikoakustik adalah bunyi kedengaran loud, booming, squeky, fluctuating dan lain-lain. Manakala contoh bagi pengukuran fizikal kepada bunyi tersebut adalah tahap, spektrum, fungsi masa dan sebagainya.

Rajah 1 di bawah menunjukkan kaedah rakaman pertama yang digunakan. Posisi mikrofon diletakkan di atas keromong dengan sudut hampir 90 darjah dan mempunyai jarak $20 \mathrm{~cm}$ di antara mikrofon dan keromong. Metod ini juga digunakan dalam beberapa kajian lepas (Hamdan et al., 2019, 2020; Meizan, 2018; Chon, 2018). Berdasarkan dari pengalaman dan pemerhatian pengkaji yang merupakan seorang penggiat dalam muzik Gamelan Melayu, kebiasaannya posisi ini digunakan bagi mendapatkan bunyi keseluruhan dari keromong semasa persembahan dan rakaman. Namun begitu, melalui pemerhatian yang dilakukan kaedah ini masih mampu diterokai. Tercetusnya idea semasa pengkaji sedang meletakkan salah satu buah keromong, didapati bahawa jika menterbalikkan keromong yang sama nada tetapi di laras yang berbeza kemudiannya diletakkan dibawah tepak keromong yang ingin disampelkan akan membiaskan gelombang dari satu nada keromong ke nada yang dibawahnya seperti dalam Rajah 2.

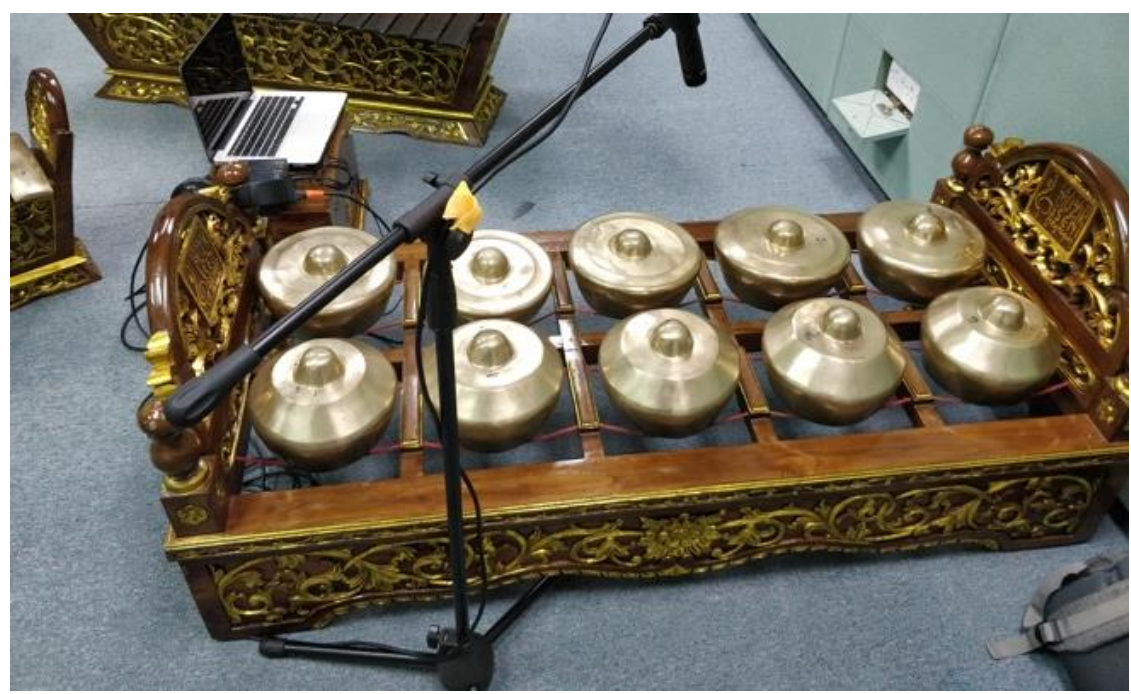

Rajah 1: Kedudukan mikrofon kaedah pertama

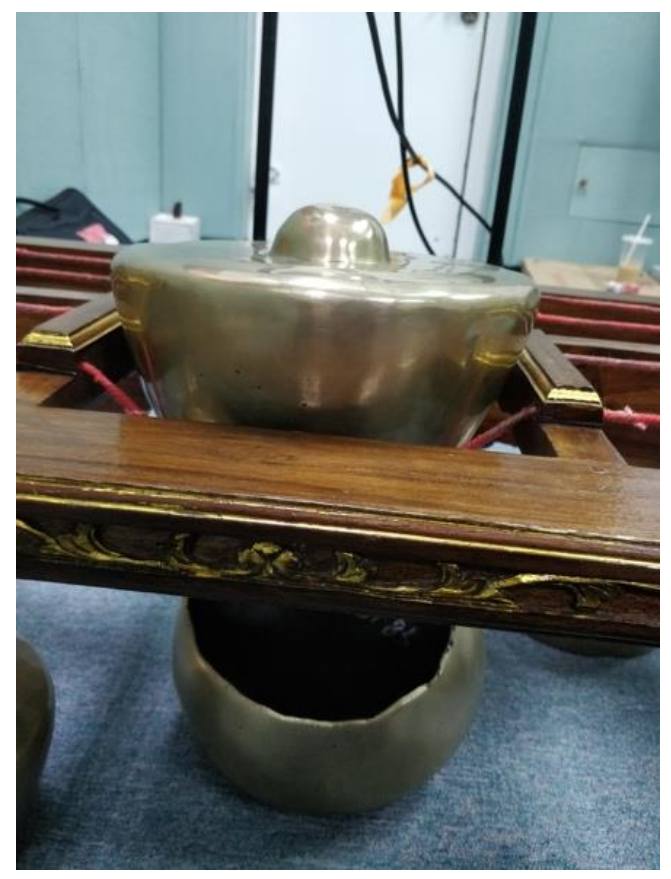

Rajah 2: Kaedah rakaman kedua 
Merujuk kepada Rajah 2 di atas, didapati bahawa gema yang dihasilkan lebih panjang dan kualiti bunyi yang dihasilkan lebih jelas. Perubahan yang dilakukan ini juga menghasilkan frekuensi yang berbeza berbanding kaedah rakaman pertama. Perbezaan frekuensi yang dihasilkan dianalisis menggunakan Virtual Studio Technology (VST) Blue Cat's FreqAnalyst Pro. Analisis dilakukan bagi melihat perbezaan variasi tekanan yang dapat dinilai menggunakan graf gelombang (Bryd \& Crawford, 2002). Bryd dan Crawford (2002) turut menyatakan, terdapat tiga cara untuk mempersembahkan bunyi dan muzik iaitu menggunakan gelombang atau audio digital, notasi muzik dan juga bentuk time-stamped event. Dalam kajian ini, pengkaji menggunakan gelombang atau audio digital sebagai representasi bunyi seterusnya disusun dalam jadual.

Terdapat beberapa langkah yang diperlukan bagi proses pensampelan audio dan ianya merupakan langkah pertama dalam menukar data analog kepada urutan nombor digital (Mutagi, 2004). Sampel audio digunakan dalam dua proses iaitu semasa proses pensampelan audio keromong dan yang kedua adalah semasa pengaplikasian GaMelLED Keromong bersama audio. Berlakunya proses penukaran data audio semasa proses pensampelan. Frekuensi yang diterima oleh mikrofon dihantar kepada audio interface lalu penukaran data analog berlaku dan ditukar kepada urutan nombor digital. Urutan audio digital ini juga divisualkan dalam perisian DAW menggunakan bentuk gelombang (Bryd \& Crawford, 2002) yang membolehkan pengkaji untuk menganalisis input sebelum disunting dan disimpan.

\section{Dapatan}

Hasil daripada eksplorasi dan cuba jaya menggunakan kaedah pertama dan kaedah kedua, didapati bahawa kedua-dua kaedah rakaman ini menghasilkan sampel audio yang berbeza namun masih dalam nada yang sama. Walaupun menggunakan peralatan yang sama dalam pensampelan audio iaitu jenis mikrofon, ruang rakaman dan peranti interface, terdapat beberapa perbezaan yang terhasil. Oleh itu, pengkaji melakukan beberapa analisis audio bagi memilih kaedah terbaik dalam pensampelan audio keromong untuk digunakan oleh GaMelLED Keromong dalam persembahan karya kreatif.

Jadual 1: Analisis Pensampelan Audio Keromong

\begin{tabular}{|c|c|c|c|c|c|}
\hline \multirow[b]{2}{*}{ Nada Keromong } & \multirow[b]{2}{*}{ Nada } & \multicolumn{2}{|c|}{ Kaedah Pertama } & \multicolumn{2}{|c|}{ Kaedah Kedua } \\
\hline & & Frekuensi & Amplitud & Frekuensi & Amplitud \\
\hline 1 & $\mathrm{Bb} 4$ & $\begin{array}{c}472 \mathrm{~Hz} \\
21 \text { cents }\end{array}$ & $-29 \mathrm{~dB}$ & $\begin{array}{l}478 \mathrm{~Hz} \\
44 \text { cents }\end{array}$ & $-56 \mathrm{~dB}$ \\
\hline 2 & $\mathrm{C} 4$ & $\begin{array}{l}268 \mathrm{~Hz} \\
43 \text { cents }\end{array}$ & $-34 \mathrm{~dB}$ & $\begin{array}{l}272 \mathrm{~Hz} \\
65 \text { cents }\end{array}$ & $-28 \mathrm{~dB}$ \\
\hline 3 & D4 & $\begin{array}{l}297 \mathrm{~Hz} \\
21 \text { cents }\end{array}$ & $-33 \mathrm{~dB}$ & $\begin{array}{c}297 \mathrm{~Hz} \\
21 \text { cents }\end{array}$ & $-24 \mathrm{~dB}$ \\
\hline 5 & $\mathrm{~F} 4$ & $\begin{array}{l}351 \mathrm{~Hz} \\
10 \text { cents }\end{array}$ & $-35 \mathrm{~dB}$ & $\begin{array}{c}356 \mathrm{~Hz} \\
32 \text { cents }\end{array}$ & $-30 \mathrm{~dB}$ \\
\hline 6 & G4 & $\begin{array}{c}389 \mathrm{~Hz} \\
88 \text { cents }\end{array}$ & $-37 \mathrm{~dB}$ & $\begin{array}{l}394 \mathrm{~Hz} \\
10 \text { cents }\end{array}$ & $-25 \mathrm{~dB}$ \\
\hline $\mathrm{i}$ & Bb5 & $\begin{array}{l}957 \mathrm{~Hz} \\
45 \text { cents }\end{array}$ & $-17 \mathrm{~dB}$ & $\begin{array}{l}957 \mathrm{~Hz} \\
45 \text { cents }\end{array}$ & $-14 \mathrm{~dB}$ \\
\hline $2^{\prime}$ & $\mathrm{C} 5$ & $\begin{array}{l}537 \mathrm{~Hz} \\
44 \text { cents }\end{array}$ & $-18 \mathrm{~dB}$ & $\begin{array}{l}544 \mathrm{~Hz} \\
66 \text { cents }\end{array}$ & $-16 \mathrm{~dB}$ \\
\hline $3^{\prime}$ & D5 & $\begin{array}{c}595 \mathrm{~Hz} \\
22 \text { cents }\end{array}$ & $-23 \mathrm{~dB}$ & $\begin{array}{c}580 \mathrm{~Hz} \\
77 \text { cents }\end{array}$ & $-19 \mathrm{~dB}$ \\
\hline 5 & F5 & $\begin{array}{c}712 \mathrm{~Hz} \\
33 \text { cents }\end{array}$ & $-24 \mathrm{~dB}$ & $\begin{array}{l}712 \mathrm{~Hz} \\
33 \text { cents }\end{array}$ & $-17 \mathrm{~dB}$ \\
\hline $6^{\prime}$ & G5 & $\begin{array}{c}799 \mathrm{~Hz} \\
33 \text { cents }\end{array}$ & $-29 \mathrm{~dB}$ & $\begin{array}{c}810 \mathrm{~Hz} \\
56 \text { cents }\end{array}$ & $-28 \mathrm{~dB}$ \\
\hline
\end{tabular}


Berdasarkan dari analisis sampel audio menggunakan kaedah pertama, terdapat frekuensi yang terhasil daripada $62 \mathrm{~Hz}$ sehingga $1600 \mathrm{~Hz}$. Frekuensi lebih tinggi di $500 \mathrm{~Hz}$, manakala bagi pendengaran subjektif pengkaji dapat menyatakan bahawa kaedah ini menghasilkan nada yang tidak jelas. Analisis audio dicatat seperti dalam Jadual 1. Bagi kaedah rakaman kedua, penelitian mendapati frekuensi keromong bermula pada $125 \mathrm{~Hz}$ sehingga $8000 \mathrm{~Hz}$. Kaedah rakaman ini mengurangkan frekuensi yang tidak diingini serta menghasilkan gema yang lebih panjang berbanding rakaman pertama. Seterusnya didapati bahawa kaedah ini menghasilkan laras nada yang lebih tepat berbanding kaedah pertama.

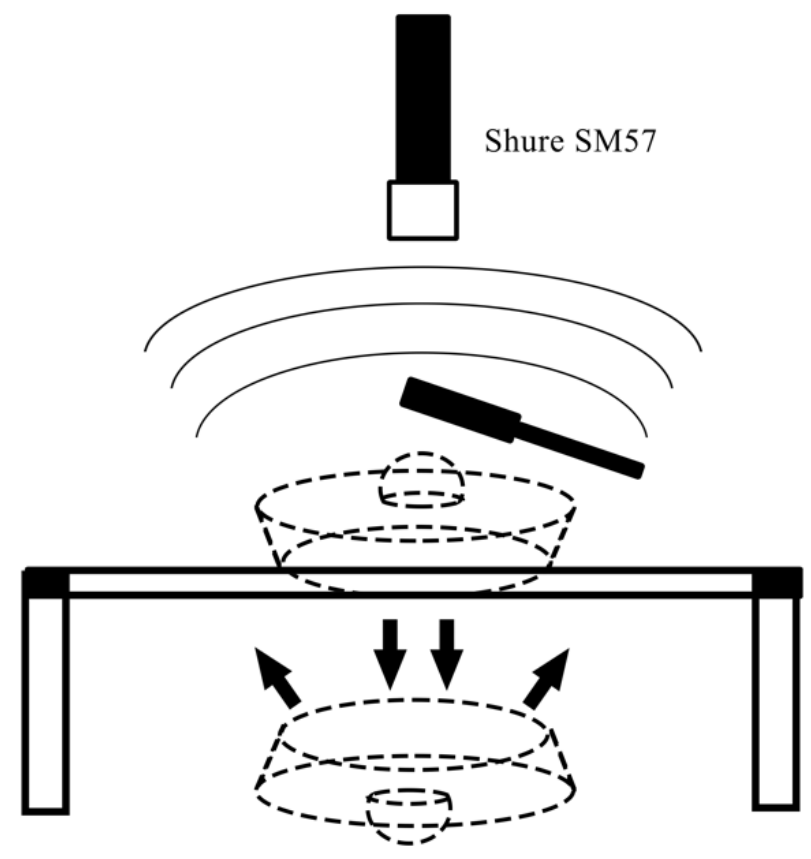

Rajah 3: Kaedah Pantul pensampelan audio keromong

Hasil proses rakaman mendapati bahawa kaedah pensampelan audio keromong yang dapat digunakan bagi pengaplikasian keromong elektronik adalah kaedah rakaman kedua seperti dalam Rajah 3 di atas yang dinamakan sebagai Kaedah Pantul. Kaedah Pantul ini menggunakan dua keromong, ketukan keromong yang di atas membiaskan gelombang ke dalam keromong di bahagian bawah (nada yang sama namun laras berbeza) lalu menghasilkan resonans yang lebih panjang dan laras nada yang lebih jelas.

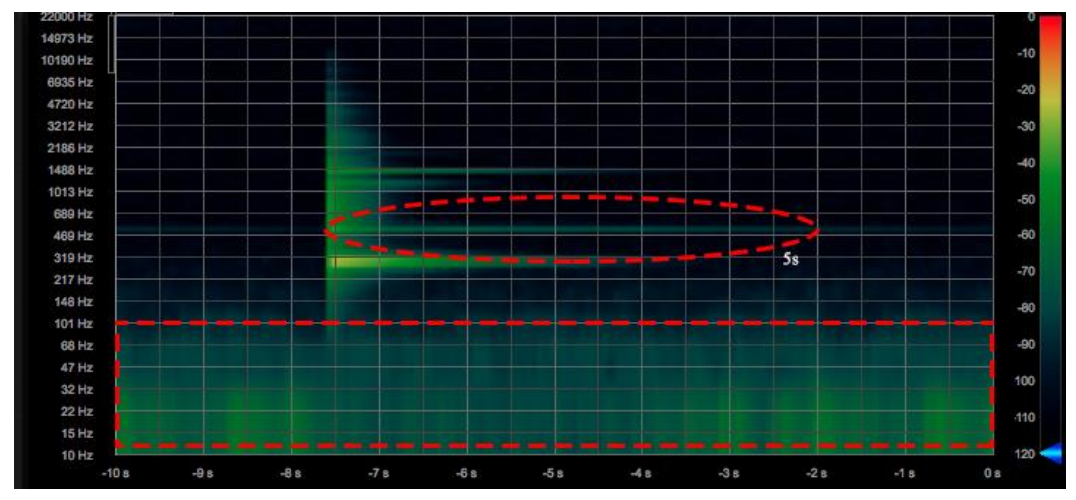

Rajah 4: Analisis sampel nada C keromong menggunakan kaedah pertama 
Merujuk kepada Rajah 4 di atas, sampel audio yang dirakam menggunakan kaedah pertama mempunyai frekuensi bising yang tidak diingini sekitar 10-101 Hz. Manakala analisis tersebut menunjukkan frekuensi bagi sampel audio ini beransur lenyap dalam jarak masa sekitar 5 saat.

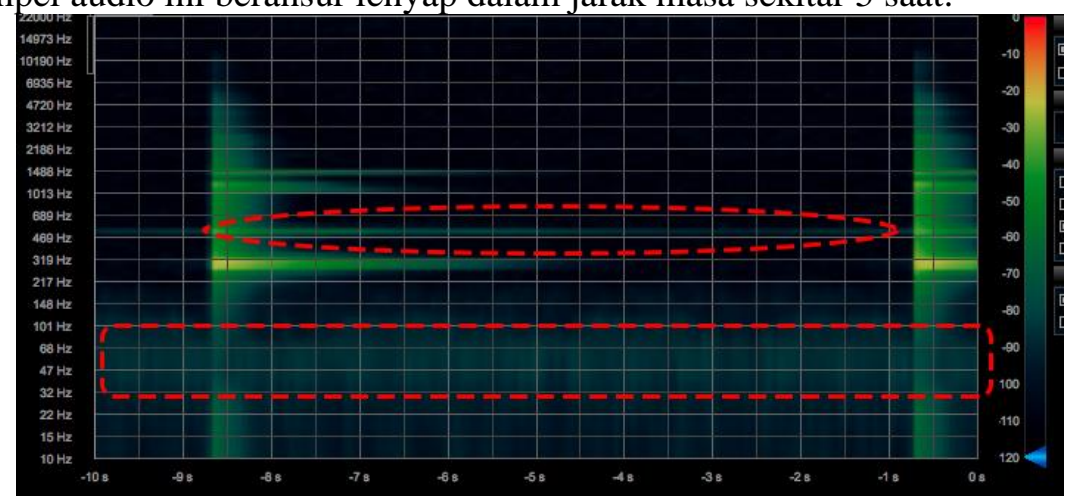

Rajah 5: Analisis sampel nada C keromong menggunakan Kaedah Pantul (Sumber: Nazimin)

Melihat kepada perbezaan analisis sampel menggunakan Kaedah Pantul seperti dalam Rajah 5 di atas, sampel yang dirakam hanya mempunyai frekuensi bising sekitar 32-101 Hz dan amplitud bagi frekuensi tersebut tidak terlalu tinggi. Manakala frekuensi bagi sampel ini mempunyai ansur lenyap sekitar 8 saat. Setelah proses analisis audio selesai, sampel audio Kaedah Pantul telah dipilih sebagai sampel audio yang dapat dipersembahkan dalam pembentangan karya kreatif. Proses akhir bagi pensampelan audio ini adalah dengan mengklasifikasikan setiap sampel mengikut nada dan laras kemudiannya disimpan ke dalam folder.

\section{Kerangka Amalan Pensampelan Audio Keromong}

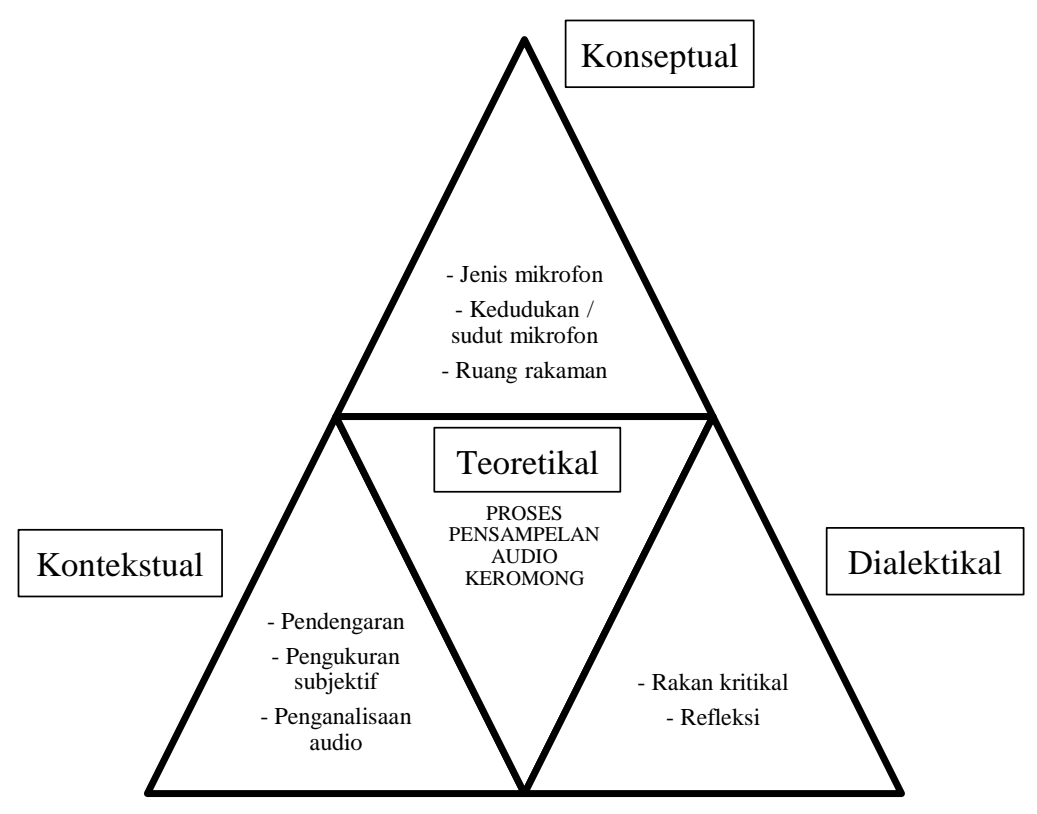

Rajah 6: Kerangka Amalan Pensampelan Audio Keromong

Rajah di atas merupakan kerangka amalan bagi proses pensampelan audio keromong yang telah dijalankan. kerangka amalan merupakan salah satu dapatan yang penting dalam kajian menggunakan kaedah PLR (Smith \& Dean, 2009). Berdasarkan dari kerangka amalan tersebut, dapat dinyatakan bahawa aspek konseptual yang menyumbang kepada proses pensampelan audio keromong adalah jenis mikrofon yang digunakan, sudut talaan mikrofon dan juga ruang bagi rakaman. Manakala aspek kontekstual pula audio dinilai berdasarkan dari pendengaran spatial pengkaji serta pengaruh rakan kritikal. Aspek kontekstual bagi proses pensampelan audio keromong ini menggunakan dua penilaian iaitu pengukuran 
secara subjektif seperti bunyi yang terlalu tajam, kurang bergema serta terlalu nipis. Selain daripada pengukuran subjektif, satu penganalisisan audio dilakukan secara terperinci menggunakan perisian audio serta visual seperti spektogram bagi menganalisis setiap aspek audio seperti amplitud, ketepatan laras dan durasi bagi setiap sampel audio. Aspek dialektikal yang digunakan dalam pensampelan audio keromong ini adalah rakan kritikal dan juga refleksi pengkaji. Audio yang telah dirakam didengarkan kepada rakan kritikal bagi mendapatkan pendapat yang berbeza. Refleksi yang dilakukan akan menghubungkan kesemua dapatan lalu menghasilkan teori bagi keseluruhan proses (Smith \& Dean, 2009).

\section{Rumusan}

Konsep utama kajian ini adalah bagi menganalisis perbezaan kaedah rakaman dalam mendapatkan sampel audio keromong yang dapat digunakan bersama GaMelLED Keromong yang telah dibangunkan. Menggunakan pendekatan Practice-led research, beberapa kaedah seperti cuba jaya, penggunaan rakan kritikal, analisis media dan juga catatan jurnal refleksi dijadikan sebagai satu kaedah alternatif dalam penerokaan kaedah rakaman audio keromong yang sedia ada. Fokus artikel ini merupakan sebahagian dari proses kajian dalam membangunkan dan mengaplikasi GaMelLED Keromong. Dapatan artikel ini turut menyumbang kepada kerangka amalan bagi proses pensampelan audio keromong yang telah diadaptasi dari Framework of Practices yang dibangunkan oleh Smith dan Dean (2009). Kerangka ini digunakan setelah beberapa penelitian dilakukan dari fasa permulaan kajian sehingga membawa kepada dapatan yang bersifat holistik.

Berdasarkan kerangka amalan tersebut, terdapat tiga amalan yang membentuk kepada pembangunan teoritikal iaitu dialektikal, konseptual dan kontekstual. Menggunakan kerangka amalan tersebut, pengkaji dapat membangunkan proses teoritikal bagi setiap keperluan soalan kajian. Bagi fokus artikel ini, amalan yang digunakan dalam kaedah kajian ini mengandungi unsur digital, teknikal dan subjektif. Sebagai contoh bagi amalan konseptual, untuk merakam sampel audio keromong terdapat beberapa aspek yang perlu ditekankan seperti kedudukan mikrofon, jenis mikrofon dan ruang rakaman. Manakala bagi amalan kontekstual pula meliputi ciri-ciri bunyi yang subjektif pendengar serta teknik menganalisis audio menggunakan alat digital mahupun analog yang sesuai. Bagi amalan dialektik pula, aktiviti contoh bagi amalan ini adalah dengan menggunakan kaedah cuba jaya semasa kajian atau mengaitkan komuniti misalnya seperti rakan kritikal bagi mendapatkan pandangan. Hasil dari tiga aspek amalan ini akan membentuk satu teori yang dapat menjadi gambaran keseluruhan proses kajian yang telah dijalankan (Smith \& Dean, 2009).

Dari aspek teknikal rakaman, satu kaedah baharu dihasilkan berdasarkan dari proses yang telah melalui fasa penelitian dan cuba jaya berdasarkan dari kaedah rakaman standard bagi keromong yang dilakukan oleh Hamdan et al. (2019, 2020), Meizan (2018) dan Chon (2018). Kaedah pensampelan audio keromong yang dinamakan sebagai Kaedah Pantul merupakan hasil eksplorasi serta cuba jaya pengkaji dalam mendapatkan sampel audio keromong yang lebih jelas serta mempunyai gema tanpa suntingan digital. Melalui Kaedah Pantul, proses pensampelan audio telah menghasilkan sampel audio keromong dalam julat frekuensi $125 \mathrm{~Hz}-8 \mathrm{kHz}$. Tiada sebarang suntingan diperlukan dalam mengekalkan frekuensi harmonik yang terhasil secara tidak langsung dari alat muzik keromong. Nada yang dihasilkan juga kedengaran lebih jelas tanpa bantuan sebarang suntingan. Sampel audio keromong yang lengkap dihasilkan bagi diaplikasi oleh keromong elektronik dalam gubahan serta persembahan. Ringkasnya, kaedah pensampelan audio yang telah dijalankan dan dianalisis merupakan satu cadangan bagi merakamkan sampel audio keromong menggunakan peralatan yang minima dengan hanya memanipulasikan posisi keromong.

\section{Rujukan}

Andreu, R., Canos, L., Juana, S. D., Manresa, E., Rienda, L., \& Tari, J. J. (2003). Critical friends: A tool for quality improvement in universities. The Emerald Research, 11(1), 31-36. http://doi.org/10.1108/09684880310462065

Anggraeni, D. P., Sukarmin, \& Nurosyid, F. (2019). Teaching sound waves using gamelan and smartphones. International Conference on Physics and Its Application, 1153, 1-7. http://doi.org/10.1088/1742$6596 / 1153 / 1 / 012123$

Boud, D., Keogh, R., \& Walker, D. (1985). Reflection: Turning experience into learning. Routledge Falmer, Taylor $\&$ Francis Group. 
Bryd, D., \& Crawford, T. (2002). Problems of music information retrieval in the real world. Information Processing \& Management, 38(2), 249-272. https://doi.org/10.1016/s0306-4573(01)00033-4

Burkner, H. J., \& Lange, B. (2017). Sonic capital and independent urban music production: Analysing value creation and 'trial and error' in the digital age. City, Culture and Society, 4(2), 29-31. http://dx.doi.org/10.1016/j.ccs.2017.04.002

Callander, S. (2011). Searching and learning by trial and error. American Economic Review, 101, $2277-2308$. http://www.aeaweb.org/articles.php?doi=10.1257/aer.101.6.2277

Candy, L. (2006, November 4). Practice based research: A guide. Creative \& Cognition Studios. http://www.creativityandcognition.com/wp-content/uploads/2011/04/PBR-Guide-1.1-2006.pdf

Chon (2018, Mac 7). Recording on bonang gamelan [Video]. YouTube. https://www.youtube.com/watch?v=lUwEpsUhfhQ

Craig, L. M., \& Parry, R. M. (2019). A real-time audio effect plug-in inspired by the processes of traditional Indonesian gamelan music. International Conference on Digital Audio Effects, 22(1), 1-8. https://www.dafx.de/paper-archive/2019/DAFx2019_paper_52.pdf

Denecke, K., \& Nejdl, W. (2009). How valuable is medical social media data? Content analysis of the medical web. Information Sciences, 179(12), 1870-1880. https://doi.org/10.1016/j.ins.2009.01.025

Dewey, J. (1933). How we think: A restatement of the reflection of reflective thinking to the educative process. D.C. Heath \& Company.

Edwards, S. H. (2004). Using software testing to move students from trial-and-error to reflection-in-action. Computer Science Education, 26-30. https://doi.org/10.1145/971300.971312

Engkur, K., Supriyatna, A., Kholid, D. M., \& Abdullah, F. (2019). The technique of playing Sundanese gamelan made from a black bamboo resonance. Proceedings of the International Conference on Arts and Design Education 2018, 255, 53-57. https://doi.org/10.2991/icade-18.2019.12

Fastl, H. (2013, Januari 9). Basics and application of psychoacoustics. Acoustical Society of America. https://doi.org/10.1121/1.4800482

Garbett, D., \& Ovens, A. (2018). Pushing boundaries and crossing borders, self-study as a means for researching pedagogy. Creative Commons Attribution 4.0 International.

Gerd, G. (2008, Disember 11). Virtual gamelan graz rules, grammars and modeling. Shaker Online. https://supercollider.github.io/book/2008/12/11/a-new-book-virtual-gamelan-graz-rules-grammarsmodeling

Gray, C. (1996, September). Inquiry through practice: Developing appropriate research strategies. No Guru, No Method. http://carolegray.net/Papers\%20PDFs/ngnm.pdf

Hamdan, S., Musib A. F., Musoddiq I. A., \& Sawawi, M. (2020). Timbre spectrum of gamelan instruments from four Malay Gamelan ensembles. Pertanika Science \& Technology, 28(2), 459-476.

https://www.researchgate.net/publication/346444198_SCIENCE_TECHNOLOGY_Timbre_Spectrum_of_ Gamelan_Instruments_from_Four_Malay_Gamelan_Ensembles

Hamdan, S., Musib A. F., Musoddiq I. A., \& Wahid, H. A. (2019). Some studies on the understanding the different tones quality in a bonang set. Journal of Engineering Science and Technology, 14(4), 1960-1973. https://www.researchgate.net/publication/346444004_SOME_STUDIES_ON_THE_UNDERSTANDING_ THE_DIFFERENT_TONES_QUALITY_IN_A_BONANG_SET

Hastuti, K., \& Khabib, M. (2016). A method for automatic gamelan music composition. International Journal of Advances in Intelligent Informatics, 2(1), 26-37. https://doi:10.26555/ijain.v2i1.57

Hill, G., \& Lyold, C. (2015). A practice-led inquiry into the use of still images as a tool for reflective practice and organisational inquiry. The International Journal of Professional Management, 10(2), 1-15. http://www.open-access.bcu.ac.uk/4035/1/Hill\%20and\%20Lloyd\%20(2015).pdf

Hummel, Z. (2016, Julai 8). Audio software (vst plugin) development with practical application [Honor's thesis, Western Michigan University]. ScholarWorks. https://scholarworks.wmich.edu/honors_theses/2688/

Jaafar, S. (2017). Lestari muzik Johor sepanjang zaman. International Conference on Local Knowledge. https://umexpert.um.edu.my/public_view.php?type=publication\&row $=N j k 2 M z c \% 3 D$

Knoblauch, H., Schnettler, B., Raab, J., \& Soeffner, H. G. (2006). Video-Analysis: Methodology and methods. Peter Lang.

Korthagen, F. (2011). Making teacher education relevant for practice: The pedagogy of realistic teacher education. Orbis Scholae, 5(2). https://doi.org/10.14712/23363177.2018.99

Leblanc, S. (2018). Analysis of video-based training approaches and professional development. Society for Information Technology \& Teacher Education, 18(1), 125-148. https://www.learnchtechlib.org/primary/p/174355/

Lydia, A. (1996). "Merapi”: A composition for gamelan and computer-generated tape. Leonardo Music Journal, 6, 7-14. https://doi.org/10.2307/1513298

Matthews, C. (2018). Algorithmic thinking and central Javanese gamelan. The Oxford Handbook of Algorithmic Music. Oxford University Press. 
Matthews, C. M. (2014). Adapting and applying central Javanese gamelan music theory in electroacustic composition and performance [Doctoral dissertation, Middlesex University]. https://eprints.mdx.ac.uk/14415/

McGuire, S., \& Pritts, R. (2007). Audio sampling: A practical guide. Focal Press United Kingdom (1 ${ }^{\text {st }}$ ed.). Routledge.

Meizan, S. (2018, Julai 11). Proses rekaman gamelan pertrack, no metronome [Video]. YouTube. https://www.youtube.com/watch?v=9SolTuU6y4I

Miklaszewski, K. (1989). A case study of a pianist preparing a musical performance. Psychology of Music and Music Education, 17, 95-109. https://doi.org/10.1177/0305735689172001

Mutagi, R. N. (2004, September 1). Understanding the sampling process. https://researchgate.net/publication/230813029

Schon, D. A. (1987). Educating the reflective practitioner: Toward a new design for teaching and learning in the professions. Jossey-Bass Higher Education Series.

Shafik, M., Jeroen, V. M., \& Stewart, J. (2014). The rough guide to Bali and Lombok ( (th $^{\text {th }}$.). Rough Guides.

Sheppard, H. M. (1967). Joget gamelan Terengganu. Journal of the Malaysia Branch of of the Royal Asiatic Society, 40(1), 149-152. http://www.jstor.org/stable/41491912

Smith, H., \& Dean, R. T. (2009). Practice-led research, research-led practice in the creative arts $\left(1^{\text {st }} \mathrm{ed}.\right)$. Edinburgh University Press Ltd.

Stenhouse, L. (1975). An introduction to curriculum research and development. Heinemann London.

Tjahyanto, A., Suprapto, Y. K., \& Wulandari, D. P. (2011). Model analysis-by-synthesis aplikasi pembangkit suara gamelan sintetik. Seminar Nasional Aplikasi Teknologi Informasi. https://journal.uii.ac.id/Snati/article/view/2226/2171

Widayanti, L., \& Pramudya, Y. (2017). Perbandingan hasil eksperimen superposisi gelombang bunyi bonang barung secara simultan dan mixing berbantuan audacity dan matlab. Spektra: Jurnal Fisika dan Aplikasinya, 2(1), 61-66. https://doi.org/10.21009/SPEKTRA.021.09

Young, H. P. (2009). Learning by trial and error. Games and Economic Behaviour, 65, 626-643. http://doi.org/10.1016/j.geb.2008.02.011 